\title{
STORAGE TANK FOR A SINGLE-PERSON HOUSEHOLD PROVIDING SAME FLOW CONDITIONS AS FOR CALIBRATION MEASUREMENTS BY WATER METER
}

\author{
Lajos Hovány
}

Original scientific paper In order to ensure the same conditions as for flow calibration, in case of a single-person household provided with a class B multi-jet propeller water meter with nominal diameter of $20 \mathrm{~mm}$, a thermally insulated storage tank was built. During the exploitation, the storage tank will be fed by calibrated constant discharges in stages. For the purposes of measured consumption cumulative curve, the needed tank volume, flow rate and minimum duration of the filling stage were defined in the function of water meter reading accuracy ( 1 litre, 0,1 litre and 0,025 litre). The measurements proved that the thermally insulated tanks were able to keep water temperature within the range identical to that measured in the water supply in a single-person household.

Keywords: single-person household; storage tank; water meter calibration; water meter reading accuracy; water temperature

\section{Rezervoar za samačko kućanstvo koji osigurava uvjete protoka jednake kao pri baždarenju vodomjera}

Izvorni znanstveni članak

Za osiguranje jednakih uvjeta mjerenja utroška vode kao pri baždarenju, za samačko kućanstvo s višemlaznim propelernim vodomjerom nazivnog promjera $20 \mathrm{~mm}$, klase B, izgrađen je termoizolirani rezervoar. Tijekom rada rezervoar će se puniti konstantnim, baždarenim protjecajem u fazama. Za izmjereni hidrogram utroška, potreban volumen rezervoara, protok i minimalno vrijeme trajanja etape punjenja utvrđeni su u funkciji točnosti očitavanja vodomjera (1 litra, 0,1litre 0,025 litre). Mjerenjem je dokazano da je termoizolirani rezervoar osigurao očuvanje temperature vode u području temperature identičnom onom izmjerenom u vodovodu samačkog kućanstva.

Ključne riječi: baždarenje vodomjera; rezervoar; samačko lućanstvo; točnost očitavanja vodomjera; temperatura vode

\section{Introduction}

According to the Measurement Protocol for Water Meters of Republic of Serbia, water meters for measuring water consumption in households need to be able to operate with errors lower than $\pm 5 \%$ (for $Q_{\min }$ ) and $\pm 2 \%$ (for $Q_{\mathrm{n}}$ and $Q_{\mathrm{t}}$ ), corresponding to the measured volume [1]. During calibration, errors of water meter operation are checked for the foreseen water volumes. Based on these volumes and discharges the duration of calibration has been calculated. For a class B multi-jet propeller water meter with a wet mechanism, having nominal diameter of $20 \mathrm{~mm}$, at water temperatures not exceeding $30{ }^{\circ} \mathrm{C}$, the required duration of calibration is $10,12,5$ and 4 minutes for $Q_{\min }=0,03, Q_{\mathrm{t}}=0,12$ and $\mathrm{Q}_{\mathrm{n}}=1,5 \mathrm{~m}^{3} /$ hour, respectively (source: "Potiski vodovodi" Ltd., Horgos, Republic of Serbia). The reading accuracy was 0,1 litre.

Water consumption (by the usage of taps, washing machine, dishwasher-machine and shower in the bathroom, likewise the flushing cistern of the toilet and the like) is characterized by the opening and closing of flow switches and the duration of water discharge from the pipeline in order to satisfy needs. The duration of consumption in households is shorter than 1 minute in 95 $\%$ of consumption cases [2].

To eliminate the effects of opening and closing the valve on the measurement errors during the calibration, the standard in force in the Republic of Serbia demands the following: "The uncertainty introduced into the volume may be considered negligible if the times of motion of the flow switch in each direction are identical within $5 \%$ and if this time is less than $1 / 50$ of the total time of the test" [3]. Other standards refer to the same recommendations as well $[4,5]$. Based on that [6] recommends the following: "Should there be doubts about whether the operation time of the valve affects the results of the tests, it is recommended that the tests should be made longer, and never under 60 seconds". Therefore by standards, errors induced by valve operation are treated only by calibration of the water meter.

The required duration of measurements for calibration discharges providing errors in the permitted range has been investigated in the hydraulic laboratory of the Faculty of Civil Engineering, Subotica, Republic of Serbia, during September 2011 and April to May 2012 [7]. According to both pressure and water flow, the water supply pipeline corresponds to the one of a single household.

Measurements have demonstrated that the minimum duration of measurements must not be shorter than:

- $\quad$ 5, 9 and 2,5 minutes for $Q_{\min }, Q_{\mathrm{t}}$ and $Q_{\mathrm{n}}$, respectively, for reading accuracy of 0,1 litre, and

- 5, 9 and 60 minutes for reading accuracy of 0,025 , 0,1 and 1 litre, respectively.

Therefore, duration of measurement corresponding to the calibrated discharges may be shorter than the duration of calibration.

To insure conditions for such measurements, storage tanks need to be installed at each household [8]. Measurements would be realized at the inlet of the storage tanks.

\section{Storage tank used in buildings}

The suggested solution is the continuation of the practice in Subotica which existed in times before the city's water supply network was built, and it is a widely used solution in settlements without permanent water supply (e.g. in Mozambique, Yemen, Jordan, Lebanon, Palestine, India, Nepal, Bolivia, Honduras, in the Mediterranean in Europe) and also in water supply networks designed in the $19^{\text {th }}$ century (for example in the 
UK) where storage tanks are used in individual family

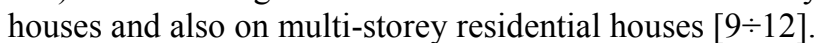

A research conducted from spring until the autumn of 2012 showed that until the early 1960's, water supply in Subotica had been provided from individual wells. Water was delivered to the consumer by buckets or it has been pumped through a pipe system into a storage tank located on the roof of the building. The tank has provided water for one or more families. Water supply systems with storage tanks on buildings, used worldwide, balance water inflow and consumption in the households, offices and shops and the tank are also used to store water for firefighting purposes [12].

In Subotica, the tank was placed on the building's attic, while the existing systems elsewhere in the world show that the tank may be placed on the roof, in the ground besides the building or even dug in the ground [1, $9,12]$.

The shape of the tank is the same in Subotica and in system used elsewhere in the world: rectangular parallelepiped and cylinder (with horizontal or vertical axis). In Subotica, tanks made of steel were found, while in the currently operating systems the tanks are made of polyethylene, PVC, polypropylene, galvanized steel, cast iron, plexiglass, fibreglass, asbestos-cement and fibre cement [12].

The levelling period could not be determined in Subotica, while in the currently operating systems it is, usually 1 day, however stagnation periods can last longer during summer (for example: for a period of 4 to 7 days). The supply of water to the storage tank may be continuous (controlled by ball float), or discontinuous (filling starts at minimum water level and lasts for $4 \div 5$ hours) [1, 12]. In Subotica, the tank for a single family was filled as long as the overflow (downstream pipe end above the kitchen window) started to operate. The needed daily volume was calculated based on the number of consumers in a household and it was $120 \div 250$ litres for each consumer [12]. The storage tank volume: in Subotica was 850 litres and $1,5 \mathrm{~m}^{3}$, while in currently operating systems it is 25 litres up to $4,5 \mathrm{~m}^{3}[9,11,12]$.

The location of the tank's inlet and outlet pipe and that of the overflow is alike in Subotica and in the currently operating tanks: the inlet pipe is connected to the tank at maximum water level (in Subotica even slightly above this level), while the outlet pipe is close to the bottom of the tank and the maximum water level in the tank is regulated by overflow [1, 12]. Storage tanks currently in use are installed with outlets [12]. The tanks in Subotica were emptied by fetching water from the tank through a bucket.

The use of thermal insulation in the existing systems is not uniform. If used, the minimum thermal insulation thickness (mineral wool, plank) of the storage tank and supply pipelines in the attic is $50 \mathrm{~mm}$. In Subotica, the steel tank was placed in a wooden box (sawdust was used as thermal insulation and the sawdust layer thickness was at least $30 \mathrm{~cm}$ and it was between the tank and wall of the box). The wooden box was set on a layer of sawdust and was closed by a plank cover (covered with multi-layers of textile and paper sacks). The pipes have not been insulated.
The problems related to the use of tanks within the existing systems are: oversized tanks, the practice of filling the tank after it has been fully emptied and that the tank is mounted on the building's roof, thus being exposed to sunlight all day long. One of the reasons for excluding water tanks on multi-storey houses in Subotica from usage was the propagation of mosquito larvae in the water of irregularly closed tanks and these larvae entered even into the taps through the supply pipes.

Aside from avoiding oversized tanks, the problems could be solved by defining the necessary volume of the thermally insulated tank in a manner that it maintains such water quality in the tank, which is similar to the one of the supply network.

\section{Temperature of drinking water}

The rate of water quality deterioration in storage tanks is higher than the rate of deterioration in the mains [12]. Deterioration of water quality is in strong correlation with the temperature of water.

Drinking water temperature values are not defined either by the 1993 WHO Guidelines for drinking water quality, or the Council Directive 98/83/EC from 1998 [13, $14,15]$. Parametric values are indicated in the Statutory Instruments of the Water Industry of England and Wales and the Protocol on the Health Safety of Drinking Water issued by Croatia in 2008 (Note: Council Directive 98/83/EC of 3 November 1998 on the quality of water intended for human consumption was taken over and integrated in this Protocol) $[16,17]$. The former sets the requirement that water temperature in household supply nets should be lower than $25^{\circ} \mathrm{C}$, while the latter stipulates that the temperature of wholesome and healthy water for human consumption does not exceed $25^{\circ} \mathrm{C}$. It means that, according to regulations and protocols, the allowed temperature of water for human consumption is up to 25 ${ }^{\circ} \mathrm{C}$.

\section{Former investigations and the target of this work}

The first sequence of measuring the warming up of the water in the thermally insulated tank was implemented from 19 December 2012 through 18 February 2013 [12]. The thermal insulation of a tank in a single-person household was checked, whose water meter reading accuracy is 1 litre. The critical volume related to this problem is the warming up of that volume of water at which the tank's filling should start $\left(V_{\text {start }}=23,5\right.$ litres $)$. The air temperature (from 30,2 up to $32,3{ }^{\circ} \mathrm{C}$ ) was higher than the value defined during water consumption measurement (from 28,5 up to $30,75^{\circ} \mathrm{C}$ ).

By correcting this air temperature-related deviation, based on new and more comprehensive examinations, this paper defines water temperature changes during a day in a thermally insulated storage tank used in a single-person household, which will be filled by permanent flow, in stages and by measuring water meter errors lower than the permitted ones, with the aim to provide water meter reading accuracy. 


\section{Determination of the volume of the storage tank and the description of the applied model}

Based on measurements of water consumption and duration of consumption conducted at a single-person household in a multi store building in Subotica, the cumulative water volume has been determined for the period of 8 August to 14 August 2012 (Fig. 1) [12].
Measurements concerning filling of toilet tanks were carried out on a 9 litres unit. When the consumption of the washing machine was considered, the moisture remaining in the laundry was also accounted for besides the water discharged by the machine. In other cases of consumption the water was first poured in a dish, consequently the regime of consumption was a bit modified.

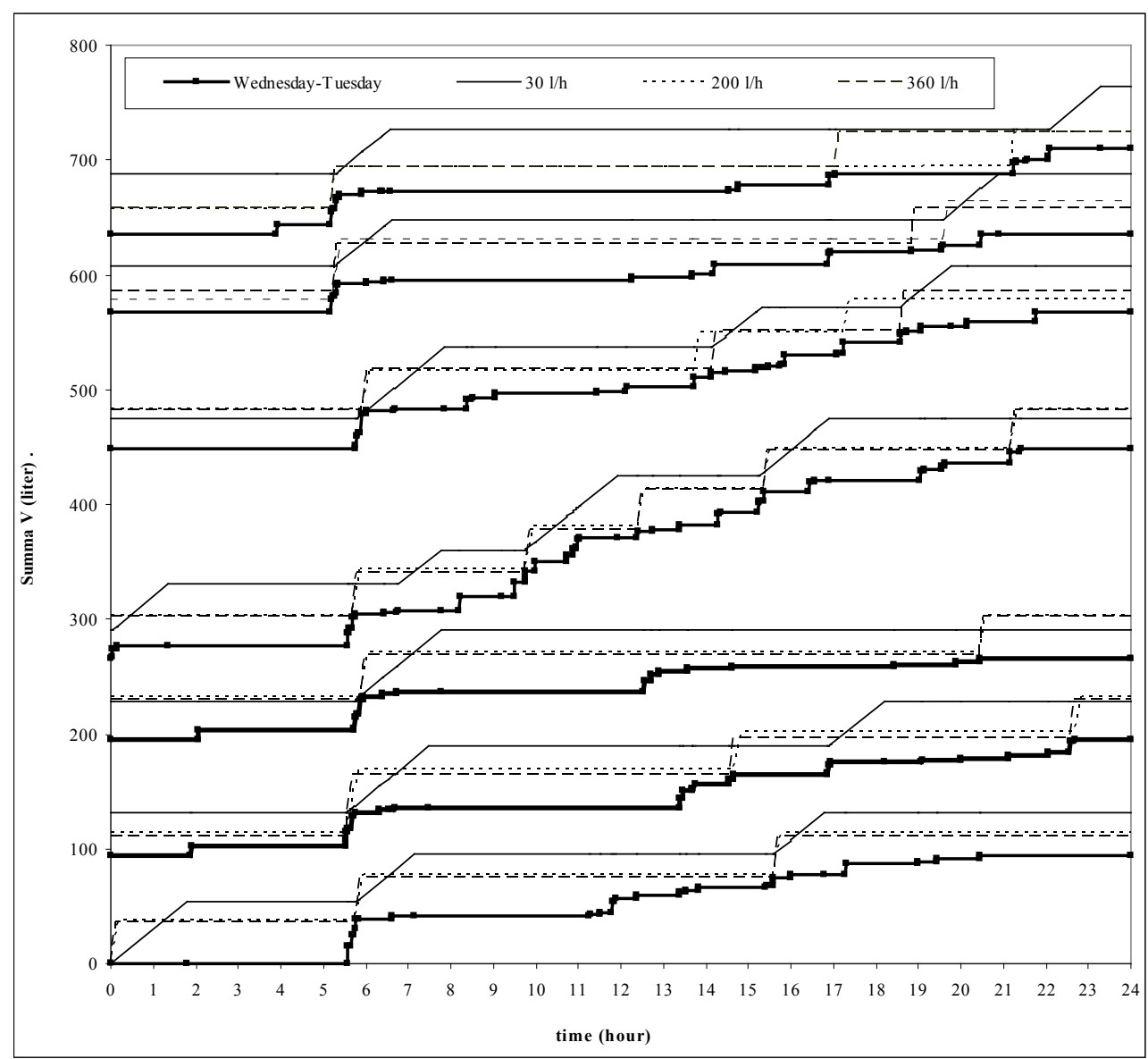

Figure 1 Water consumption cumulative curve from 8 August (Wednesday) through 14 August (Tuesday) 2012 in a single-person household in Subotica and tank filling cumulative curves with flows of $Q_{\mathrm{p}}=30,200$ and 360 litres/hour

From 1 to 7 September of the same year, the water temperature (water discharge from the tap in a duration of 1 minute was measured) and the air temperature in the flat were measured as well.

The minimum flow $Q_{\mathrm{p}}$ and the duration of tank filling $t_{p}$ in the function of water meter accuracy have been determined (Tab. 1).

Table 1 Discharge and duration of tank filling in function of the accuracy of the water meter

\begin{tabular}{|c|c|c|c|}
\hline $\begin{array}{c}\text { Accuracy of } \\
\text { water meter } \\
\text { reading } \\
\text { (litre) }\end{array}$ & $\begin{array}{c}\text { Minimum } \\
\text { measurement } \\
\text { duration } \\
\text { (minute) }\end{array}$ & $\begin{array}{c}\text { Discharge } \\
\text { of tank } \\
\text { filling, } Q_{\mathrm{p}} \\
(1 / \mathrm{h})\end{array}$ & $\begin{array}{c}\text { Duration } \\
\text { of tank } \\
\text { filling, } t_{\mathrm{p}} \\
\text { (minute) }\end{array}$ \\
\hline 0,025 & 5 & 360 & $5,1 \div 9,1$ \\
\hline 0,1 & 9 & 200 & $9,1 \div 16,9$ \\
\hline 1 & 60 & 30 & $61,5 \div 128,8$ \\
\hline
\end{tabular}

Cumulative water volume curves are shown in Fig. 1. The following was determined for these conditions:

- filling the tank should start when the volume of the water in the tank has dropped to $V_{\text {start }}=6$ (for water meter reading accuracy of 2,5 centilitres), 8 (for water meter reading accuracy of 1 decilitre) and 23,5 litres (for water meter reading accuracy of 1 litre) and

- filling the tank should be stopped, when the volume of the water in the tank has reached $V_{\text {stop }}=36$ (for water meter reading accuracy of 2,5 centilitres), 38 (for water meter reading accuracy of 1 decilitre) and 53,5 litres (for water meter reading accuracy of litres).

The thermally insulated storage tank was filled up to a certain level by water of temperature not exceeding 23,5 ${ }^{\circ} \mathrm{C}$ from the water supply system through an inlet pipe (Fig. 2)

By maintaining air temperature between 28,5 and $30,75^{\circ} \mathrm{C}$ during the test, the warming up of the water in the tank was observed. 


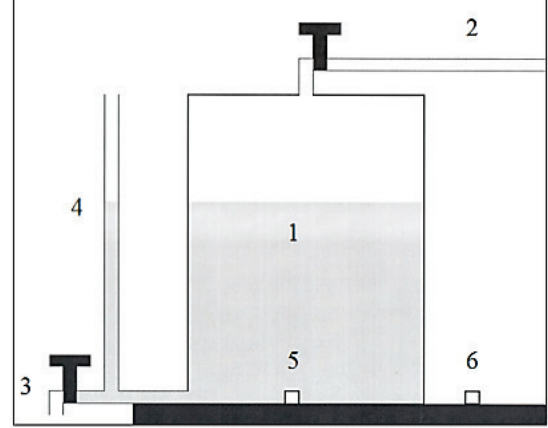

Figure 2 Installation for measuring water temperature changes in the thermally insulated storage tank (1): 2 - inlet pipe, 3 - outlet pipe, 4 scaled pipe to define water volume in the tank, 5 - data logger to monitor water temperature changes in the tank, 6 - data logger to monitor air temperature changes around the storage tank

During subsequent measurements related to water warming up duration in thermally insulated tanks, similar to those ended on 18 February 2013, a plastic barrel of 60 litres capacity was used, which was thermally insulated by $10 \mathrm{~cm}$ thick fibreglass and was built-in a plywood box with a bottom made of $5 \mathrm{~cm}$ thick plank (Fig. 3) [12].

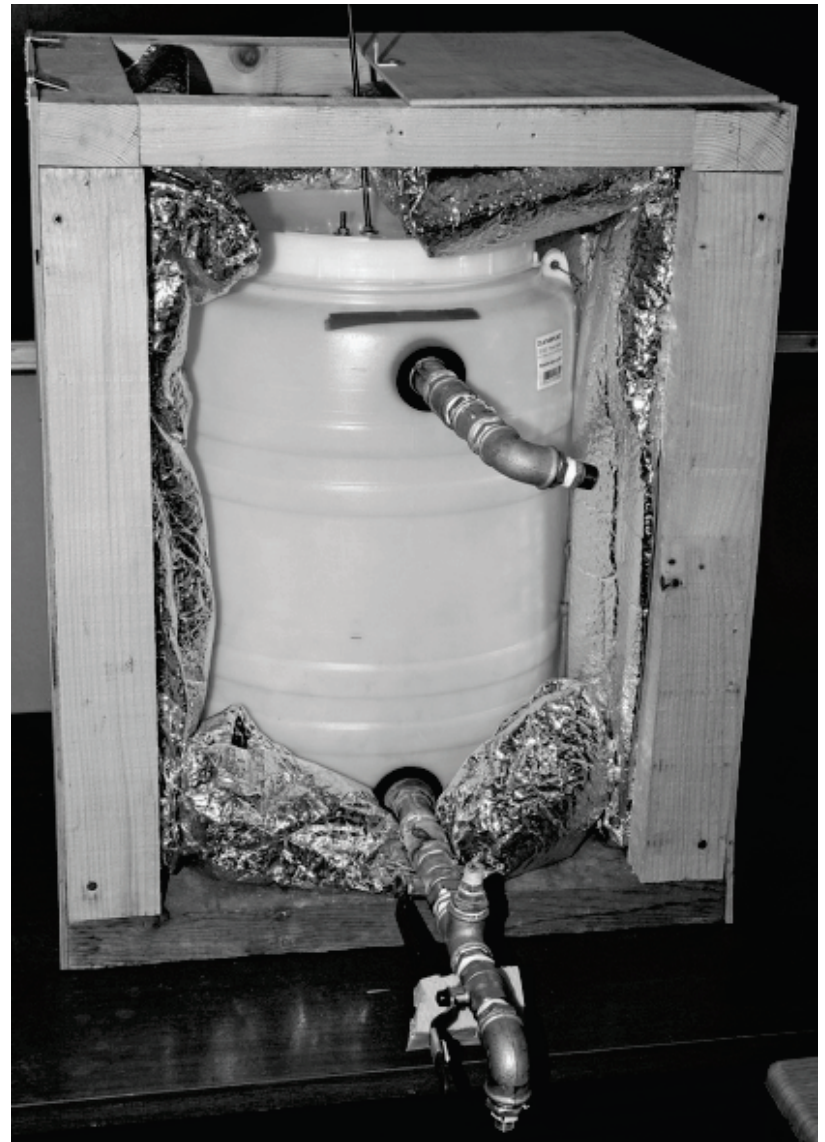

Figure 3 Storage tank - plastic barrel capacity of 60 litres - installed in box, prior to thermal insulation

The $10 \mathrm{~cm}$ thick glass wool and the box (sides and cover) were wrapped in reflective bubble foil insulation. The barrel has been filled by water through an inlet pipe on the top of the barrel, and it has been drained through the bottom outlet. The barrel had an overflow as well.

For following up the temperature of the water in the tank and the air around the storage tank, data loggers type TidbiTv2 Temp (Part\#UTBI-001), produced by HOBO were used. Data were memorized in 1-minute intervals.

\section{Results of measurements}

Measurements were made from 17 March through 14 July 2013. For two to six days, the warming up of water quantities of 8,$5 ; 23,5 ; 38,5$ and 53,5 litres were monitored in the tank. The number of such measurements was between 3 and 10 . The air temperature changed from 28,6 to $30,5^{\circ} \mathrm{C}$ during the summer period. Owing to these measurements, the time required for warming up the storage tank water from 23,75 to $25^{\circ} \mathrm{C}$, and from 23,75 to $27,25^{\circ} \mathrm{C}$ was defined (Figs. $4 \div 6$ ).

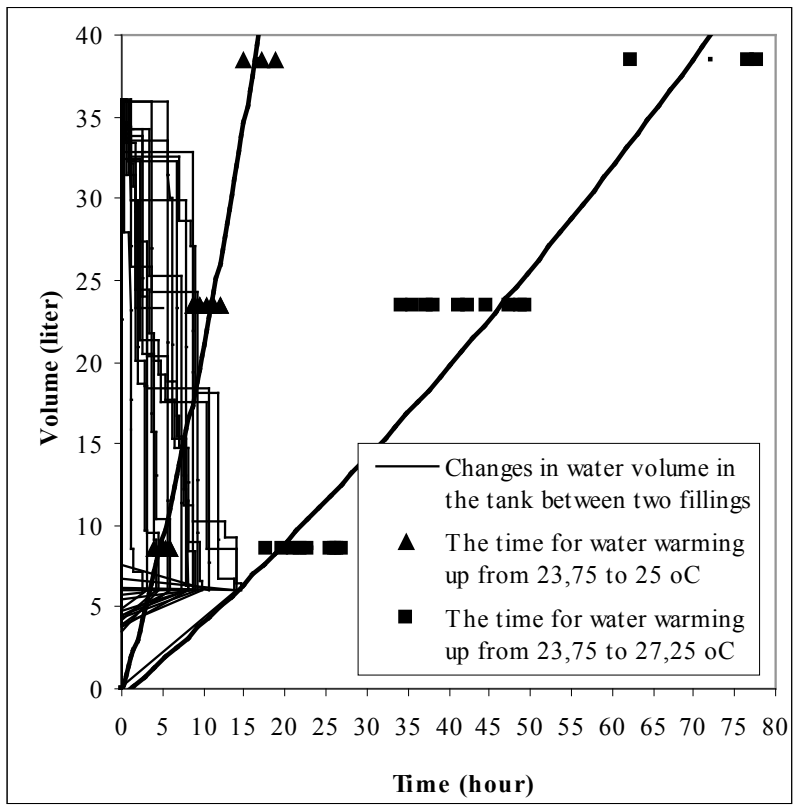

Figure 4 Changes of water volume in the storage tank between two fillings and water warm up-times from 23,75 to $25^{\circ} \mathrm{C}$ and from 23,75 to $27,25^{\circ} \mathrm{C}$, respectively for water meter accuracy of 2,5 centilitres

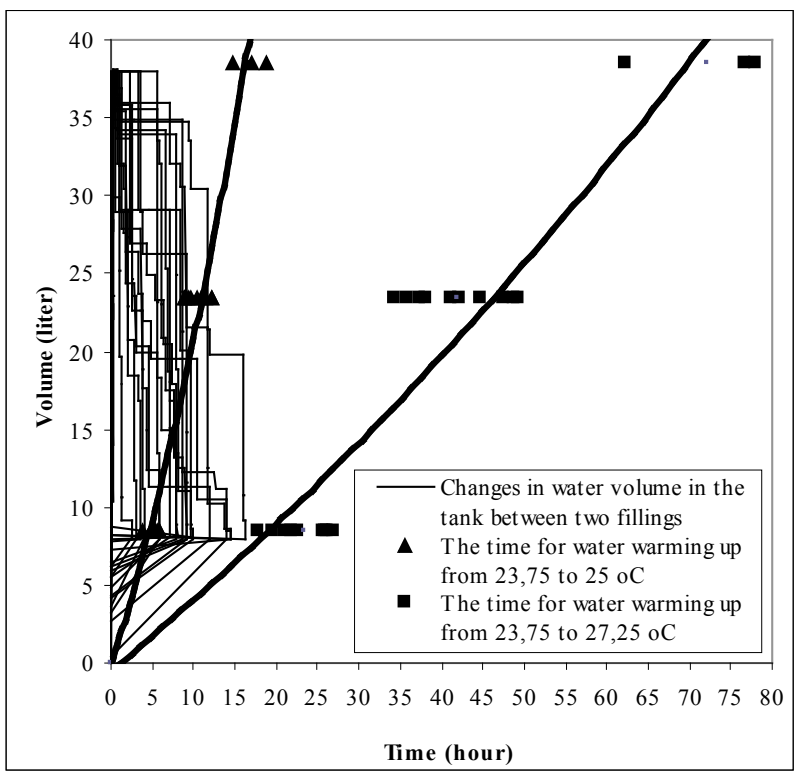

Figure 5 Changes of water volume in the storage tank between two fillings and water warm-up times from 23,75 to $25^{\circ} \mathrm{C}$ and from 23,75 to

$27,25^{\circ} \mathrm{C}$ respectively, for water meter accuracy of 1 decilitre

Dots on the mentioned graphs refer to measured data regarding water temperature rise of the above mentioned volumes. In order to make it more clearly, a curve has been fitted to the measured values, showing the warming- 
up period from $23,75^{\circ} \mathrm{C}$ to $25^{\circ} \mathrm{C}$, and from $23,75^{\circ} \mathrm{C}$ to $27,25^{\circ} \mathrm{C}$ for different volumes of water. The same figures show as well the change of storage volume in the period between two fills. It has been assumed that rise in temperature of water commences in all cases with the filling of the tank.

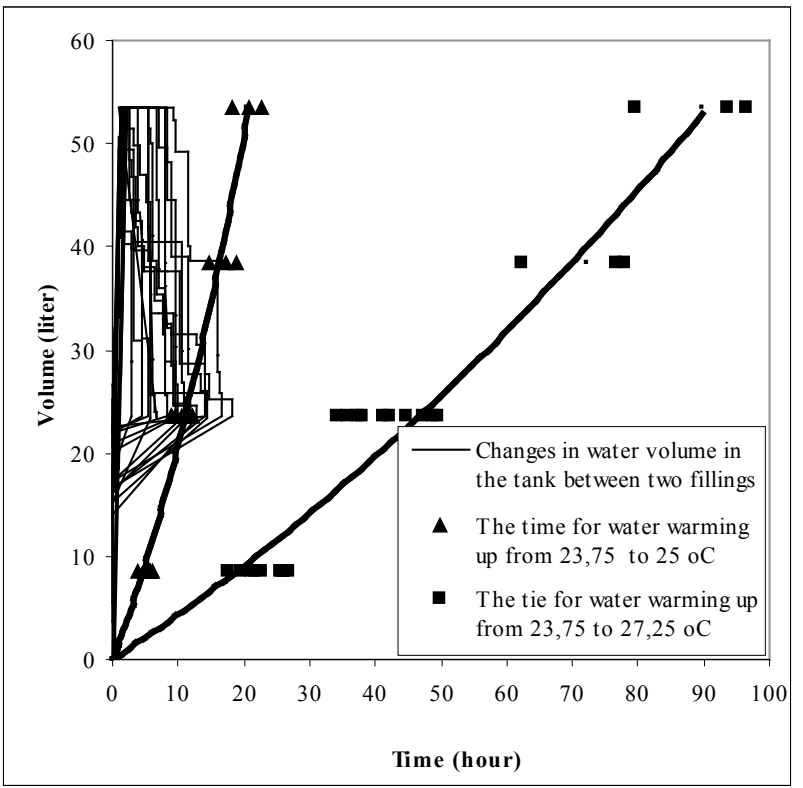

Figure 6 Changes of water volume in the storage tank between two fillings and water warm-up times from 23,75 to $25^{\circ} \mathrm{C}$ and from 23,75 to $27,25^{\circ} \mathrm{C}$, respectively for water meter accuracy of 1 litre

\section{Discussion and application of the results}

Besides the cumulative consumption curve, in case of a single-person household the required volume of the storage tank ensuring conditions for proper flow measurements - similar to those during calibration depending on reading accuracy has been determined by measurements as $V_{\text {stop }}=36$ to 53,5 litres. These tanks belong to the rather small category of currently used tanks. To ensure flawless water supply for a single person household, a regime of tank filling is proposed.

In relation to measurements made from 19 December 2012 through 18 February 2013, subsequent measurements showed that the warming up time of $V_{\text {start }}=$ 23,5 litres of water quantity $(6 \div 7,6$ and $21,3 \div 27$ hours $)$ has increased $(8,8 \div 12,1$ and $34,3 \div 49,4$ hours $)$ [12]. The solution is given for water meter reading accuracy of 1 litre. Measurements proved the following: if the storage tank $V_{\text {stop }}=53,5$ litres is filled by the household's water supply network having temperature of $23,75^{\circ} \mathrm{C}$, the water never warms up above $27,25{ }^{\circ} \mathrm{C}$ during the observed week.

For checking the thermal insulation of the tank with water meter accuracy of 2,5 centilitres and 1 decilitre, the critical volume $V_{\text {start }}$ was 6 and 8 litres, respectively (Figs. $4 \div 6$ ). The chance of keeping water temperature below $27,25{ }^{\circ} \mathrm{C}$ decreases with the rise in readings-accuracy of the water meter. The examined thermal insulation is at the limits of acceptability at tanks of $V_{\text {stop }}=36$ and 38 litres.

Therefore, thermal insulation of tanks:

- provides opportunity for water consumption measurements by water meter (with various reading accuracy) in similar conditions like during the calibration,

- keeps water temperature within a range characteristic to the water supply network of a household.

For the control of tank filling, it is proposed to mount an electromagnetic valve (Hunter, PGV-101) at the downstream end of the tank's supply pipe, while the on/off control of this valve can be enabled by a probe for water level measuring in the tank. While emptying the tank at $V_{\text {start }}$ the probe would open the electromagnetic valve to fill the tank by flow $Q_{\mathrm{p}}$ during $t_{\mathrm{p}}$ time. When the required water quantity has been achieved in the tank $V_{\text {stop}}$, the probe will shut the electromagnetic valve.

Through measurements made from 1993 to 1998 in the Anglien Water in the UK it has been determined that the specific consumption of a single-person household was 211 , of a two-person household was 154 , of a threeperson household was 130, while of a four-person household was 122 litres/person/day [18]. Increase in the specific water consumption by the decrease of the number of persons in a household was also confirmed by measurements made from October 2009 through March 2010 on part of Queensland in Australia [19].

The number of single-person households is increasing in Europe [20]. It is estimated that one third of the households in England will be single-person households by 2020 [21]. The rise in the number of single-person households compared to the number of persons in multiperson households is more expressed in new households: three fourths of new households in London will be singleperson households by 2026 , while $60 \div 90 \%$ of new households in Australia will be single-person ones by $2030[22,23]$.

Adjusting water consumption measurements to error values lower than the permitted ones and maintaining water quality in the tank, which is similar to supply net water quality, in single-person households is a problem which will concern at least one third of the households in the structure of future settlements.

The following supports the idea of using tanks in households: a) the use of unmeasured flow reducer on the outlet pipe of the tank could reduce pipeline water losses, and $b$ ) the use of these tanks will reduce the design flow of the municipal pipeline [12]. Reduction of the daily flow variations will produce more uniform flow in the pipeline network in the streets, hence it will reduce water stagnation in the mains, thus improve water quality in the supply network.

\section{Conclusions}

Based on pilot measurements, lasting a week, conducted in a single-person household, meeting criteria:

- that the storage tank was filled in regime ensuring conditions similar to those during calibration,

- $\quad$ applying the proposed protocol of filling, the required volume of the storage tank depending on reading accuracy has been determined as $V_{\text {stop }}=36$ to 53,5 litres.

Regarding the filling procedure it is proposed to install an electromagnetic valve (Hunter, PGV-101) at the 
downstream end of the tank's supply pipe, while a water level probe could be used to control the operation of the valve.

The storage tank was made of plastic barrel, thermally insulated by $10 \mathrm{~cm}$ thick glass wool (wrapped in polyethylene air-bubble foil), then mounted in a plywood box (wrapped in polyethylene air-bubble foil) with $5 \mathrm{~cm}$ thick plank bottom.

During the experiment (performed from 17 March through 14 July 2013), the air temperature was within the temperature range measured in the single-person household during the summer period.

Therefore, thermal insulation of tanks:

- provides opportunity for water consumption measurements by water meter (with various reading accuracy) in similar conditions like during the calibration,

- $\quad$ keeps water temperature within a range characteristic to the water supply network of a household.

Similar investigations are required regarding multiperson households. Furthermore, besides temperature, water quality check should be extended to other parameters as well.

\section{References}

[1] Pravilnik o metrološkim uslovima za vodomere. Službeni list SFRJ, Beograd, 51, 1986. http://www.dmdm.rs/PDF/ MusMup/MUS_vodomeri.pdf. (4.03.2014).

[2] Buchberger, S. G.; Wells, G. J. Intensity, Duration, and Frequency of Residential Water Demands. // Journal of Water Resources Planning and Management. 122, 1(1996), pp. 11-19. DOI: 10.1061/(ASCE)0733-9496(1996)122:1(11)

[3] SRPS EN 14154-3:2010 (en). Water meters. Part 3: Test methods and equipment.

[4] ISO 4064-3:2005(E). Measurement of water flow in fully charged closed conduits - Meters for cold portable water and hot water. Part 3: Test methods and equipment.

[5] OIML R 49-2:2006 (E). Water meters intended for the metering of cold potable water and hot water. Part 2: Test methods.

[6] Arregui, F.; Cabrera Jr. E.; Cobacho, R. Integrated Water Meter Management. IWA Publishing, London, 2006.

[7] Hovanj, L. Uticaj neustaljenog tečenja vode u vodovodu na grešku merenja vodomera. // Zbornik radova sa 16. Naučnog savetovanja Srpskog društva za hidraulička istraživanja (SDHI) i Srpskog društva za hidrologiju (SDH) Donji Milanovac / Beograd, 2012, pp. 271-280.

[8] Hovany, L. Error in Water Meter Measuring Due to Shorter Flow and Consumption Shorter than the Time the Meter was Calibrated. // Water Supply System Analysis - Selected Topics / AviOstfeld. Rijeka : InTech, 2012, pp. 131-149.

[9] Tamari, S.; Ploquet, J. Determination of leakage inside buildings with a roof tank. // Urban Water Journal. 9, 5(2012), pp. 287-303. DOI: 10.1080/1573062X.2012.660959

[10] Andey, S. P.; Kelkar, P. S. Influence of Intermittent and Continuous Modes of Water Supply on Domestic Water Consumption. // Water Resources Management. 23, 12(2009), pp. 2555-2566. DOI: 10.1007/s11269-008-9396-8

[11] Shrestha, M.; Buchberger, S. G. Role of Satellite Water Tanks in Intermittent Water Supply System. // World environmental and water resources congress 2012, Crossing boundaries / Albuquerque, 2012, pp. 944-951.

[12] Hovány L. Providing the Conditions for Domestic Water Consumption Measurement by Water Meter. // Proceedings. $5^{\text {th }}$ IEEE International Symposium on
Exploitation of Renewable Energy Sources / Subotica and Óbuda, 2013, pp. 11-15.

[13] Guidelines for drinking water quality. World Health Organization, Geneva. 2008. http://www.who.int/ water_sanitation_health/dwq/fulltext.pdf. (10.12.2013).

[14] Council Directive 98/83/EC of 3 November 1998 on the quality of water intended for human consumption. // Official Journal of the European Communities, 5.12.1998, pp. L 330/32-L 330/54.

[15] Dalmacija, B. (Nosilac projekta) Strategija vodosnabdevanja i zaštite voda u AP Vojvodini. Univerzitet u Novom Sadu Prirodno-matematički fakultet Departman za hemiju, Novi Sad, 2009. http://www.eko.vojvodina.gov.rs/files/file/dokumenti/sajt\% 20 strategija\%20vodosnabdevanja\%20i\%20zastite $\% 20$ voda \%20apv.pdf. (10.12. 2013).

[16] Regulations: The Water Supply (Water Fittings) Regulations 1999. Water Industry, England and Wales. Statutory Instruments. $\quad$ No. 1148. http://www.legislation.gov.uk/uksi/1999/1148/pdfs/uksi 19 991148_en.pdf. (12.07.2012).

[17] Pravilnik o zdravstvenoj ispravnosti vode za piće. Narodne novine, Zagreb, 17. Travnja 2008. http://narodnenovine.nn.hr/clanci/sluzbeni/339082.html. (11.12.2013).

[18] Post 135 (2000). Water efficiency in the home. Parliamentary Office of Science and Technology, London, March 2000. http://www.parliament.uk/post/pn135.pdf. (27.01.2014)

[19] Fielding, K.; Spinks, A.; Russell, S.; Mankad, A. Water Demand Management Study: Baseline Survey of Household Water Use (Part B). // Urban Water Security Research Alliance Technical Report No. 93, 2012. http://www.urbanwateralliance.org.au/publications/UWSR A-tr93.pdf. (4.03.2014).

[20] Berkholz, P.; Kobersky, V.; Stamminger, R. Comparative analysis of global consumer behavior in the context of different manual dishwashing methods. // International Journal of Consumer Studies. 37, 1(2013), pp. 46-58. DOI: 10.1111/j.1470-6431.2011.01051.X

[21] Hall, R.; Ogden, P. E.; Hill, C. Living alone: evidence from England and Wales and France for the last two decades. // Changing Britain: Families and Households in the 1990s / Susan McRae. Oxford, New York: Oxford University Press, 1999, pp. 265-296.

[22] Richter, Ch. P.; Stamminger, R. Water Consumption in the Kitchen. A Case Study in Four European Countries. // Water Resources Management. 26, 6(2012), pp. 1639-1649. DOI: $10.1007 /$ s11269-012-9976-5

[23] Newton, P.; Meyer, D. The Determinants of Urban Resource Consumption, 2012. http://eab.sagepub.com/ content/44/1/107. (4.03.2014).

\section{Author's address}

Lajos Hovány, hydraulic engineer, Ph. D.

University of Novi Sad,

Faculty of Civil Engineering Subotica,

Kozaračka 2a, 24000 Subotica, Serbia

E-mail: hovanyl@gf.uns.ac.rs 